\title{
WOMEN AND POLITICS: SOCIAL CONSTRUCTION AND A POLICY OF DECONSTRUCTION
}

\author{
Kartini Aboo Talib Khalid \\ Institute of Ethnic Studies, Universiti Kebangsaan Malaysia, 43600 Bangi Selangor, Malaysia
}

Received 2014-06-18; Revised 2014-06-30; Accepted 2014-09-11

\begin{abstract}
Female representation in politics is not unusual but the significance can be questionable. Women's involvement in politics has been minimal in Malaysia. The improvement in the number of female representatives over the years has been surprisingly slow. Thus the political landscape is still a man's world. Although the number of female registered voters is higher than male, women's representation in the parliament fails to reflect this societal majority. The feminist perspective argues that deterrent factors to women's active involvement are due to social construction and such a claim is supported when reviewing this phenomenon. Women are still viewed as the supportive group and unfit to lead the society. Despite the National Policy for Women that was adopted to deconstruct such double standards for women, the struggles for women in politics are tremendous. This research applies the qualitative method to examine women and politics. Secondary data is gathered to challenge the claim that the National Policy for women has empowered women in politics. This article examines the meaning of social construction and deconstruction mechanisms that are unable to boost women's participation in politics. Overall, women are certainly capable of carrying out political responsibilities but the miles to significant political participation are still far.
\end{abstract}

Keywords: Gender, Politics, Policy, Participation

\section{INTRODUCTION}

The struggles that occur with regard to women are everywhere in this world. Khalid (2009) argues that the forms, issues, intensities and capacities of grievances may be diverse but women are facing a constant gender struggle for equality. Approaches to encourage women's participation in politics, the economy and society involve local and international organizations. The United Nations (UN) led other organizations in recognizing women's participation by declaring the International Year of the Woman in 1975, which was known as The Mexico Declaration, proclaiming the Women's First Decade (1976-1985) as a ten year plan for a Platform of Action. Here the UN played a vital role providing avenues and strategies for women around the world to work on improving their status in society. Simultaneously with this international effort, Malaysia has adopted the UN Platform of Action by establishing its first National
Policy for Women. This policy is a mechanism to channel efforts, energy and materials to not only improve women's participation but also to empower them.

This policy and its platform of action have been referred to as a guideline when assessing women's participation in all sectors including politics, the economy and society. A national policy is assumed to work with the full commitment from state and non-state actors in order to improve disadvantages pertaining to women's issues. A policy provides the vision to pursue justice and equality through fundamentally championing women's voices and actions. One such fundamental manifestation of action can be realized significantly through women's representation in parliament. The complexities of gender participation through the voices and actions of representatives in parliament are tremendous. Women must work twice as hard as men to convince central committee members in each political party to be listed as election candidates. In fact, most 
political parties give priority and better opportunities to male rather than female candidates. The traditional fatalistic mindset of gender stereotyping is still very present and damaging.

\section{METHODOLOGY APPLICATION}

This research applies a qualitative method in analyzing the issue of women's participation in politics. Secondary statistical data were gathered from the Election Commission of Malaysia, the printed document of the National Policy for Women and newspapers both printed and online for current information on the General Election of 2013. Analytical interpretation was developed utilizing these secondary data to contextualize evidence and to support the arguments on a national policy for women regarding empowerment. Many government documents including the national policy for women were reviewed to outline the historical background of several international and local events or meetings on women in which the government participated.

This information helps to map the frequency of events, actions or inaction and decisions made by the government. Additionally the qualitative method holds the view that reality is socially constructed and hard to measure, thus interpretation can be applied in analyzing the data that uses words to describe the phenomenon of interest (Neuman, 2006).

Secondary statistical data are reported as received. The analysis involves an examination of the data to explain the possible aspects that impede the implementation of the national policy for women and their participation in politics. A critical analysis requires the researcher to move beyond the documents in order to assess the institutions, structures and processes that encompasses the national policy and its relationship with women in politics (Harrison, 2001). Thus, arguments are built based on evidence with a critical approach to investigating factors and implications.

\section{A NATIONAL POLICY: QUESTIONS OF DECONSTRUCTION}

Women's development in Malaysia has been primarily influenced by international events. Khalid (2009) notes that the agendas and strategies for women and development were referred to the Mexico Declaration and other platform of actions at the international and local levels. Additionally other international conferences were significant such as the Nairobi convention in 1985, the Commonwealth
Secretariat Meeting on Women in Nassau, Bahamas, the Commonwealth Plan of Action in Vancouver and the conference on women's affairs in Harare, Zimbabwe in 1987. All encouraged the Malaysian government to deliver programs for women and development through HAWA (Jabatan Hal Ehwal Wanita or Centre for Women) later in year 2001, the name was changed to JPW (Jabatan Pembangunan Wanita or Department of Women Development). Moreover all events contributed to the establishment of a National Policy for Women in 1989. Intensive reviews and research on documents gathered at the international resolutions were done deliberately. As a result, a National Policy for Women was a careful agenda that integrated international resolutions into local needs. It is a policy that has been modified and redefined to fit the Malaysian national development.

As a result, the overall objectives of the National Policy for Women (See the Sixth Malaysia Plan (19911995), Economic Planning Unit, Prime Minister Secretary Department: Malaysia) are as followed:

- To ensure equitable sharing in the acquisition of resources and information as well as access to opportunities and benefits of development, for both men and women

- To integrate women in all sectors of national development in line with their abilities and needs in order to improve the quality of life, eradicate poverty, abolish ignorance and illiteracy and ensure a peaceful and prosperous nation

Based on these goals, the national agencies for the advancement of women are creating agendas and activities that conform to the stated goals of the National Policy for Women. The capacities and capabilities of HAWA are strengthened to carry out its diverse functions effectively. Consequently, this policy allows active intervention from Non-Governmental Organizations (NGOs) that are now partners with the government to oversee programs for enhancing women's participation. The government provides counseling, training efforts and other support services to NGOs whose core services are based on women's affairs. This joint cooperation is a formula toward maximizing commitments to better equip the programs that have been designed for women. Both objectives monitor women's participation in all sectors consistently.

Furthermore this policy legitimizes efforts to identify problems illustrating women's participation at various levels of employment: Professional, technical, administrative and managerial, clerical, sales, services, 
agriculture and production. Moreover data for women's participation in politics includes the number of women representatives in both the Senate and the House of Representatives. This policy also promotes strong women's participation in politics with the target of at least $30 \%$ women representatives in Parliament. Such representation would enable strategic maneuvering of women's agendas for development in secured decision making positions. Unfortunately the efforts of deconstructing gender stereotypes through this policy are not progressing as expected.

\subsection{Women and Politics: Where is our Female Representative?}

Mulakala (2013) notes that women's political representation in Southeast Asia is approximately $18 \%$, which is below the global average and Malaysia is ranked the second lowest in the region with only $10 \%$ of women representatives. The incidence of female representation can be found in politics but their significance can be questioned. In the early stages, women's participation in politics was trivial and subtle. Although there has been improvement in the number of women in politics over the years, the political landscape is still dominated by male representatives. Table 1 provides information on women's participation in politics from 1959 until 2013.

Based on Table 1, female representatives in parliament are outnumbered by their male counterparts. Although the number of female representatives is increasing with every election, the significance is considered weak. In 2008 there were 24 female representatives out of 222 total seats in parliament and the percentage of $10.81 \%$ was viewed as weak and insubstantial to influence the parliament on policy making. Unfortunately, the recent general election of 2013 showed that the number of female representation remained the same. Additionally, in year 2008, out of 24 female representatives only two were holding full ministries portfolios, three held positions as deputy ministries and the rest were representatives of their elected areas with no major position in the ministries. This scenario marks an important finding that even as the number of women representatives increases with every election, their influence is still inadequate. A similar scenario is displayed currently in parliamentary seats. Minimal portfolios are given to women representatives: Two are holding full ministries portfolios and five are appointed as Deputy Ministers to different government ministries. The remaining representatives from the opposition parties work to represent the people of their constituencies and could face difficulty in mobilizing their position to push women's issues onto the political agenda.

Fortunately the total number of female candidates increased almost $40 \%$ in this 2013 election with a total of 168 candidates compared to 120 candidates in 2008 (SPR, 2013). Table 2 displays the comparative number of female candidates in 2008 and 2013 for each political party competing in the general elections. Although there was a significant increase in the total number of female candidates, the impact was minimal because of limited female participation in politics. Additionally, Table 2 also reflects that both Barisan Nasional (BN) and Pakatan Rakyat that composed of Parti Islam Semalaysia (PAS), Democratic Action Party (DAP) and Parti Keadilan Rakyat or People's Justice Party (PKR) increased their female candidates in both parliamentary and state seats in 2008 and 2013. In 2008, BN had 13 female candidates competing for the parliamentary seats and 23 for the state seats, while Pakatan Rakyat had 11 female candidates for the parliamentary seats and 18 for the state seats. For Pakatan Rakyat, 2008 marked an unexpected political tsunami that surprised them with their significant wins. BN lost its $2 / 3$ majority seats in the parliament despite a slim victory. The same fate of losing a $2 / 3$ majority in parliament repeated itself in the 2013 election resulting in a win for BN but a loss of seven (7) parliamentary seats to Pakatan Rakyat.

The previous election results showed a huge shift in votes and support from BN to Pakatan Rakyat, resulting in Pakatan Rakyat putting a tremendous effort into placing more female candidates in both parliamentary and state seats in 2013. Needless to say BN is now also committed to increasing number of female candidates in both houses. For the parliamentary seats both BN and Pakatan Rakyat have an equal number of candidates, 22 in total, but Pakatan Rakyat has more female candidates in the state seats than BN (Pakatan Rakyat with 55, BN with 49 candidates). It has been suggested that in order to be considered a strong presence, female representation should reach at least $30 \%$ in any voting body (Fox, 1992). In other words, the increased number of women representatives must be consonant with the number of women representatives holding important positions in ministries because increasing number of female representatives alone garners no power. Unfortunately the present decrease in women representatives in parliament is already a setback to the whole objective of the National Policy for Women and it seems that the target of at least 30\% female participation in politics is far-fetched. 
Table 1. Gender representatives in Parliament, 1959-2013

\begin{tabular}{|c|c|c|c|c|c|}
\hline \multirow{2}{*}{$\begin{array}{l}\text { Year of election } \\
1959\end{array}$} & \multicolumn{2}{|c|}{ Female representative (\%) } & \multicolumn{2}{|c|}{ Male representative (\%) } & \multirow{2}{*}{$\begin{array}{l}\text { Total seats in } \\
\text { parliament } \\
104\end{array}$} \\
\hline & 3 & 2.90 & 101 & 97.10 & \\
\hline 1964 & 3 & 2.90 & 101 & 97.10 & 104 \\
\hline 1969 & 2 & 1.38 & 142 & 98.62 & 144 \\
\hline 1974 & 5 & 3.25 & 149 & 96.75 & 154 \\
\hline 1978 & 7 & 4.54 & 147 & 95.46 & 154 \\
\hline 1982 & 8 & 5.19 & 146 & 94.81 & 154 \\
\hline 1986 & 7 & 3.95 & 170 & 96.05 & 177 \\
\hline 1990 & 11 & 6.11 & 169 & 93.89 & 180 \\
\hline 1995 & 15 & 7.80 & 177 & 92.20 & 192 \\
\hline 1999 & 20 & 10.30 & 173 & 89.70 & 193 \\
\hline 2004 & 23 & 10.50 & 196 & 89.50 & 219 \\
\hline 2008 & 24 & 10.81 & 198 & 89.19 & 222 \\
\hline 2013 & 24 & 10.81 & 198 & 89.19 & 222 \\
\hline
\end{tabular}

Table 2. Female candidates in general election, 2008-2013

\begin{tabular}{|c|c|c|c|c|}
\hline \multirow[b]{2}{*}{$\begin{array}{l}\text { Election year } \\
\text { Political party }\end{array}$} & \multicolumn{2}{|c|}{2008} & \multicolumn{2}{|c|}{2013} \\
\hline & $\mathrm{P}$ & $\mathrm{S}$ & $\mathrm{P}$ & $\mathrm{S}$ \\
\hline$\overline{\mathrm{BN}}$ & 13 & 23 & 22 & 49 \\
\hline PAS & 3 & 5 & 7 & 18 \\
\hline DAP & 4 & 9 & 4 & 18 \\
\hline PKR & 4 & 4 & 11 & 19 \\
\hline Independent & 0 & 0 & 12 & 0 \\
\hline Total & 24 & 41 & 56 & 112 \\
\hline
\end{tabular}

Source: The Election Commission Malaysia (2013).

Note:

P-Parliamentary seat

S-State seat

In fact, the division created by female representatives of the ruling BN party and the opposition party, Pakatan Rakyat, will even stretch the scarcity farther due to conflicts of interest and ideology.

Another interesting factor is the tremendous increase of women as independent candidates in the 2013 election, from zero in 2008 to 12 in 2013 . One reason for such a sudden increase was the conflict of interest between a candidate and her central party's decision that appeared in both BN and Pakatan Rakyat. For instance, Kamilia Ibrahim (UMNO-BN) was a Deputy Chief of Wanita UMNO before she was ousted from the party for deciding to compete as an independent candidate. She disagreed with the party chief, Najib and his decision over the list of candidates that would be placed on the ballot for the election. Kamilia Ibrahim denied that Najib had offered her a seat to compete in the election and she complained that the rank and file in $\mathrm{BN}$ were still running female candidates as supplementary and unimportant to the party (Yusof, 2013). However, Najib responded that she was the one who refused to compete for the Bukit Chandan seat that was offered to her
(Habib, 2013). Kamilia Ibrahim's personal grudge did not position her well for the election. She lost her competition for the Kuala Kangsar seat in Perak to a BN candidate, Wan Mohammad Khairil Anuar Wan Ahmad with a big defeat of 447 to 14,218 ; the PAS candidate who competed for the same seat earned 13,136 votes (SPR, 2013).

In another incident a female candidate from DAP, Janice Lee, a former Teratai assemblyman, decided to compete as an independent candidate but lost. Her declaration to compete as an independent candidate set her against the DAP party's rules and regulations (Star, 2013). The DAP decided to expel her for failing to publicly withdraw from contesting as an independent candidate. Lee later filed a suit against DAP over her expulsion from the party. She claimed that her expulsion should be nullified based on an investigation by the Registrar of Society that revealed the election of the party's central executive council members held last year was not in accordance with the DAP constitution. Lee then sought a declaration for her membership in DAP since 2001 to be reinstated immediately (FMT, 2013).

Both Kamilia Ibrahim and Janice Lee were defeated in this general election, but their courage to challenge the Central Committee Members in their parties marked a strong dimension of women that are willing to stand independent though the consequence expelled them from being members to their party. They were willing to take the risk and hold to what they believe was correct at that time. However, the decision to challenge the Central Committee Members is hardly accepted in strong hierarchical organizations like UMNO and DAP. Although the party's rule and regulation is clear on this matter, their objection to top rank members will end up in a misery even in a context of questioning party's agenda. 
The general election of 2013 also highlighted competitive female candidates between the $\mathrm{BN}$ and Pakatan Rakyat parties. Both political alliances were fiercely competing to secure as many seats as possible at the parliamentary and state levels. Selected female candidates were believed by the Central Committee Members of each alliance to be the winning candidates that could challenge their political opponents. Pakatan Rakyat was daring enough to allow a few celebrities to be the running candidates for its party banner. While, Barisan Nasional stick to its original mandate in selecting its female candidates based on their popularity among party members, education level, track record as members of the party and the origin of a candidate to local voters that she will represent, for instance, a candidate that was born in a state where she came from is assumed to have a better chance to convince the local voters. Table 3 below displays a comparative analysis of female candidates from the $\mathrm{BN}$ and Pakatan parties competing for parliamentary and state seats in 2012 and 2013. Based on Table 3 below, seats won by BN and Pakatan were similar in total but $\mathrm{BN}$ won 13 parliamentary seats compared to Pakatan that only managed to secure 10 seats. On the other hand, Pakatan Rakyat obtained 30 seats at the state levels compared to BN with 27 state seats.

Women candidates play a subordinate role in the political parties and especially in the BN victory of 2013 . The winning of a seat in a first-past-the-post election system in Malaysia has defined winners and losers and for 56 years BN's overall victory has been assisted by Borneo's fixed deposit package of Sabah and Sarawak (Kessler, 2008). Both states show the most parliamentary seats reserved to them despite their small population density when compared to the Peninsular region. Based on a report by the Election Commission of Malaysia, voters registered for the 2013 election were 13 million people and female voters constituted $50.23 \%$ while male voters were $49.7 \%$. There were 168 female candidates in this 2013 election compared to 120 female candidates in the previous election year of 2008. The total number of female candidates for year 2013 increased by $40 \%$ from the previous election (2008). Even though women candidates worked as hard as their male counterparts to convince voters with many campaign ads and actions including public talks, door-to-door introductions, dinner table talks and donations, they were far less well represented than men among competing candidates. While the percentage difference is small, the disparity between the female voting population and women representatives in parliament is large.
Table 3. Female Candidates in the General Election of 2008 and 2013 between Barisan Nasional and Pakatan Rakyat

General Election 2008 (GE 12)

\begin{tabular}{llll} 
& Parliament & State & Total \\
\hline Party of alliance & 13 & 23 & 36 \\
Pakisan Nasional & 11 & 18 & 29 \\
General Election 2013(GE 13) & & & \\
Barisan Nasional & 13 & 27 & 40 \\
Pakatan Rakyat & 10 & 30 & 40 \\
\hline
\end{tabular}

Source: Amended from the Election Commission Malaysia, 2013

However, there is an effort among female representatives in Parliament to establish a woman's caucus in order to represent women's issue in development more cohesively. Members are invited from both BN and Pakatan Rakyat. Azalina from the UMNO-BN leads the caucus and other ranking positions are reserved equally for opposition female members of parliament (See Azalina Pengerusi Kaukas Wanita Parliament Penggal ke-13, July 16 2013 at MStar Online http://mstar.com.my (accessed online July 22, 2013)). There is a strong movement among female representatives to put aside their political differences in the name of gender and development because issues for women affect all of their constituents. Although it is clear that any success story garners extra mileage for the ruling party, the benefits will be shared by the opposition party as well. Empowering women opens them up to critical reviews of women and urges them to be rational in making their decisions for a better future.

In an election, the large number of female voters is essential to the winning or losing, but gender is never an issue in determining winning or losing candidates. Voters are likely to choose or to reject candidates based on several factors including political party, local issues, a party's manifesto or political agenda for improvement, a candidate's track record, scandals, public relations and engagement with people, a party's ideology and personality. These criteria cut across gender lines when it comes to choosing candidates in an election. If gender is not an issue, why are the numbers of female candidates and representatives so low? The social construction model posits some answers based on women's reproductive roles, masculinity in a patriarchal society and vertical power decisions that prevent women from becoming leaders. The feminist perspective provides a framework to understand women's struggles for equality in this context. 


\section{THE FEMINIST PERSPECTIVE: A POLICY FOR DECONSTRUCTION}

Bensimon and Marshall (2003) argue that the feminist perspective is key when examining social phenomena related to gender. Features such as a focus on power relations at various sectors of involvement, a concern for justice where there is a the need to comprehend cultural constraints and a desire to establish a contextual understanding of different cultural processes are a guideline for assessing how far the National Policy for Women has contributed to empowering women in politics. The feminist analysis adds that it is an illusion that the increased numbers of women participating in politics does not reflect the accomplishment of the National Policy of Women, particularly women's participation in politics with any substantive value.

After decades of implementation of the National Policy for Women, the power at the top level is still concentrated in the hands of male counterparts. The number of woman participants has increased over the years especially in the employment sectors but female workers worked as assistants that occupy positions such as secretaries or supportive staff where their opinions or votes did not count in a decision-making process. Power is defined hierarchically and the determination of power resides in the top level of organizations primarily populated by male workers. Thus a policy that would enhance women's participation in all sectors becomes marginal. A rational top down policymaking structure may overlook the gender factor because opportunities and skills needed to maximize or accomplish high productivity and efficiency may also be seen in women. Consequently outcomes such as productivity and efficiency do not recognize gender as pivotal to profit making. The vision to pursue justice in gender relations, particularly in economic development, seems to challenge the neo-liberal perspective (O'Brien et al., 2000). The neo-liberal perspective is concerned with improving market efficiency through limited state intervention, trade liberalization and unregulated competition. In contrast, the feminist perspective is concerned with social justice, issues of right and wrong, equality in access in employment and education. This approach relies on state intervention to assign value to women's work. Therefore intervention in a free-market economy is a distortion of the market (O'Brien et al., 2000). As a result, women face incredible obstacles in presenting their perspective of gender equality to economic sectors both to international organizations and local institutions.
Furthermore, applying a system based on merit that defines skills and qualification may be a standard assessment tool, but a merit system that constrains opportunity for women is unfair and unjust. A merit system defined by men from its inception could be seen as having been socially constructed to meet the needs of male participants. With interpretations biased in favor of men's needs as the gold standard, it is difficult to deconstruct these notions from the top down or the bottom up. Herein women's roles and participation become substandard and devalued. A research by Kahu and Morgan (2007) validates this circumstance through their findings in New Zealand. When viewed through the feminist rhetorical perspective, they found that policy documents were designed primarily to achieve economic objectives rather than the needs of women. Often agendas for development become dry and ineffective because of partial participation from women. Efficient and productive development requires significant participation from both sexes at every level of government and society. Hence, gender is a fundamental issue and policy analysis that derives from a feminist perspective takes into account and goes beyond genderexplicit and gender-neutral practices which may advantage women, men and transgender persons (Bensimon and Marshall, 2003).

In addition, an approach that is gender-conscious provides ways to transform a power concentrated organization into a practical practice organization through delegation of work that may reduce abuses and corruption of power. For instance in a Malaysian report during the years of 1994-1997, out of 1,264 people arrested for bribery and corruption, only $2.2 \%$ or 28 persons were women (A text speech delivered by the first lady of the Fourth Prime Minister of Malaysia, Datin Sri Dr. Siti Hasmah Mohd Ali in Dewan Muktamar Pusat Islam, Kuala Lumpur on 29th August 1998). These figures suggest that women are less likely to receive bribes and to commit any corrupted acts. Although this information is too limited to generalize women as more accountable than men, the idea of embracing the feminist analysis is vital, because it reveals the taken-for-granted policies that may underestimate women's capabilities to work. The feminist approach is not simply adding women into the agenda for development but it encourages changes that represent better interpretation of participation to all and improved power relations as well (Hawkesworth, 1994).

Regardless of its popularity, the feminist perspective highlights the concern for justice where the need to 
comprehend power relationships has been overlooked by policy makers who have been directly or indirectly involved with the National Policy for Women. Policy for development that claims to have included women's participation is still relegating women to their feminine sectors and overlooking their potential impact. Women still lag behind in terms of participation in politics and development. In fact, the force to empower them must be acknowledged at the top before an explicit impact can be realized. Restrictions on women's participation should be lifted.

Reviewing policies for development from a feminist perspective would help to create awareness of any possible unintended gender bias embedded in the policy. One way of achieving this goal is to encourage more women representatives to be involved at the decision making level.

Furthermore, forms of cultural constraints need to be addressed to establish a contextual understanding of different cultural processes and to assess how cultural constraints have deterred women's participation in politics. Recognizing other factors that deter women's participation could explain the reasons behind the low percentage of women in politics, a sector dominated by men even after the National Policy for Women has been implemented. Cultural constraints have affected women and placed them in a subordinate role in society. Therefore commitments to improve women's participation must first understand the obstacles that impede them from participating in politics and further prevent them from claiming equal power positions in society.

\section{SOCIAL CONSTRUCTION: A PERSISTENT ISSUE}

Social constructionism is a concept that attempts to question the nature of reality. Murphy et al. (1998; Hammersly, 1992) note thatconstructionism is antirealist and it promotes a stance of relativity. Furthermore, (Hacking, 1999) views social construction as a pre-existing condition that is shaped by society including what the society believes about needs, values or interests. The shaping of beliefs is done through reinterpretation of the subject based on experiences that later becomes norms. The word constructionism is a post-modern term focusing on society rather than the individual whose subjective experiences challenge the patterns observed by scientific inquiry. The element of skepticism in post modernism is likely to deconstruct the existing social reality and redefine it with a perspective that challenges the meaning of it.
Bensimon and Marshall (2003; Appiah and Guttman, 1998; De Beauvoir, 2012) argue that gender roles are not inevitable but are rather the product of social forces. Burr (2003) suggests that a person's identity originates not from inside the person but from the social realm. Thus socialization takes place through significant others who mediate the objective reality of society, render it essential and meaningful and in this way the product of socialization is internalized by individuals (Berger and Luckman, 1991). Logically there is no scientific evidence to explain a physical or biological correspondence between a woman's gender and pervasive roles such as cooking, cleaning, child rearing and other traditional roles. When women entered the workforce these traditional roles were transformed into modern but low-paying jobs such as janitors, clerks and receptionists. Non-professional jobs stigmatize women and often relegate them to work befitting mental simplicity: Easy, straight forward jobs with low payment are for women while complicated, mentally intensive jobs and higher salaries are for men.

Friedl (1975; Sanday, 1981) posit that social construction on the basis of physical fitness has long existed in tribal societies where men are referred to as physically strong and tended to be warriors, hunters and processors of hard raw materials; women were nurturing children, cooking and preparing food for families. Firestone (1974) argues that women's biological reproductive capability is the root of their oppression, particularly when some tasks may conspire to limit their capacity, energy and freedom. In addition, Marini (1990) notes that social influences in a traditional society further extend into modern society that give men the privilege, power and status that is seldom shared by women. Such social construction and influence have led to stereotyping and this deters women from social mobilization in all sectors.

A similar stereotyping paradigm precludes women's participation in politics. Women's reproductive roles label them too vulnerable, emotional and weak when compared with men. Prejudices such as women are likely to gossip are used to suggest that women are unfit to be effective leaders when compared with men. Therefore, a woman is required to be extra assertive in order to be accepted as a politician while a man is easily accepted regardless of his education or integrity. This masculine domination in a patriarchal society like Malaysia limits women's political participation because they are viewed as weak, powerless and too emotional to decide on weighty issues effecting society. Thus social construction argues that the drop in women's 
participation in politics, particularly after the 2013 general election, is due more to society retaining traditional patriarchal paradigms about women's timidity and lack of ambition. The glass ceiling issue remained a very real issue in this millennium when men as political leaders and actors decided to limit female candidates in the 2013 election. Consequently, the current percentage of women representatives in parliament became minimal and less than in 2008 .

Another consequence of fewer women participating in politics after the general election of 2013 is the pattern of a few female candidates that decided to compete as independent candidates due to disagreements with their central political party's decisions. Such issues appeared not only in BN but also in Pakatan Rakyat. UMNO historically ousted the greatest number of party members (61) for choosing to run as independent candidates including Kamilia Ibrahim (Kuala Kangsar, Perak), Sharif Omar (Tasek Gelugor, Penang), Suhaimi Mohd Ghazali (Sepang, Selangor) and Badaruddin Tun Mustapha (Semporna and Senallang, Sabah). By comparison Pakatan Rakyat only expelled Janice Lee (Teratai, Selangor), Sim Tong Hin (Kota Melaka), Ng Lam Hua (Mengkibol, Johor) and Yew Tian Hoe (Aulong, Perak). Conflict between members and the central committees in a political party is common. If a political party's member decides to compete as an independent candidate, then he or she will be expelled (See Clause 20.10 of the UMNO Constitution which states that any UMNO member contesting in the general election as independent candidate will be expelled from the party and their membership cannot be accepted foreverhttp://www/thestar.com.my/News/nation/2013/04 /22GE13-Umno-Sacks-61-including-former-Wanita-No 2-Kamilia Ibrahim-Update (accessed online July 28, 2013)). The repercussions of such action are certain. To violate a party's principles of loyalty and adherence is unthinkable and termination is not executed along gender lines.

A central committee decision could be based on the probability for a running candidate to win in the constituency assigned to him or her for either parliamentary or state seats, or both. A political party acts rationally to run a viable candidate to secure its party's victory. Wining is a priority and thus a party's decision to reserve only a small number of seats for female candidates could be best for the party. Nevertheless women have shown their efficacy with their wins in the general election of 2013. All they needed was the faith and trust of the central committee members to assign them the job. If the central committee members dominated by men are still implementing vertical power decisions and retaining this irrational doubt about women's abilities and credibility, the number of female candidates will remain small and insignificant.

There is a subtle gender issue among most voters. They rationally vote for a candidate especially based on a few essential factors including political party, a party's manifesto, good governance principles, a good track record of services, absence of scandal, public relations and societal engagement. A candidate's personality that is built from his or her societal engagement, absence of scandal and clean track record would influence voters' decision. The central committee members in a political party must be able to adopt these factors rather than gender in selecting a party's candidate for election. For instance, in GE 2013, when Nurul Izzah from PKR fought against Raja Nong Chik Raja Zainal Abidin (UMNO) for the Lembah Pantai parliamentary seat, voters' decisions did not reflect a gender issue. Izzah won with 31,008 votes, Raja Nong Chik obtained 29,161 votes and Rosli Baba (an independent candidate) garnered only 167 votes. Similarly in Halimah Saddique (UMNO) against Muhammad Said Jonit (PAS) for the Johor Tenggara parliamentary seat, Halimah had a landslide victory with 25,698 votes while Muhammad obtained only 8,502 votes (See Tujuh Wanita Besi Kukuh Martabat Wanita Dalam Kepimpinan Negara, Berita Harian 22 Mei 2013 di). More incredible victories go to the other 21 female candidates either from BN or Pakatan Rakyat that won their seats despite the fact that they were competing against other female or male candidates.

It is clear now that limited social mobilization to women in politics is socially constructed by a group of individuals in a patriarchal society that views women as a subordinate group. Although the establishment of the National Policy for Women is meant to deconstruct such hard-core stereotypes against women, the implementation mechanism must be improved. A process to recognize women's roles must begin with family, schools and community and then private business and society will follow. The role of women must be redefined because in this millennium modernism and post-modernism clash. Women are required to play a critical role outside their traditional realm but must also be able to balance their feminine nurturing role as a mother in a family. These two different roles demand sacrifice and hard work, yet women are bold and determined. The understanding of women's duality or multiple roles needs to be established and approached through social institutions 
that would help accelerate societal change. Social institutions such as community services, schools, religious bodies and NGOs that support women's participation must provide a positive image continually and must denounce stereotyping symbols and actions that penalize women.

\section{CONCLUSION}

The National Policy for Women is a rubric designed to integrate women into the country's development for the past twenty-three years. However the strength to empower women particularly in politics is still weak. This policy should gather its efforts to enhance the socialization process, especially modeling positive and discouraging negative stereotyping in early childhood socialization, so that a society that is less gender biased can be developed. Additionally, this policy should be a platform that lifts unnecessary requirements that impede women in Malaysia from fully participating in society. The form of rules, policy and division of positions at federal and state levels are structurally gendered in many ways.

Thus, women are deferred from participating fully when the posts at both levels including appointment, tasks, administration, work hour and etc. are insensitive to women's need. Yet, lamenting such discouraging participation from women due to their self preference that dislike politics because the burden is best carried by men. Still, it is unfair to blame it on women when the structure of governance is gendered highly. Then, if ways of influencing the majority in parliament are difficult, women should start thinking of alternative ways to be empowered. They can utilize the community approach by pulling funds and resources internationally and domestically to elevate women into a better position in politics and economy. Legal enforcement could be utilized as a mechanism to ensure that this policy is applied to all private and public entities dealing with access to women's participation in all sectors. Women are persuasive to make gender a visible issue, but the change of paradigm requires men of integrity who are not afraid of equality.

\section{ACKNOWLEDGMENT}

This research is sponsored by the grant code LRGS/BU/2011/UKM/CMN/04 and DPP-191-2014. The author would like to thank and acknowledge $\mathrm{Dr}$ Karen Vautour of Massachusetts, USA for her contribution in editing and proof reading this manuscript.

\section{REFERENCES}

Appiah, K.A. and A. Guttman, 1998. Color Conscious: The Political Morality of Race. 1st Edn., Princeton University Press, Princeton, ISBN-10: 1400822092, pp: 200.

Bensimon, E.M. and C. Marshall, 2003. Like it or not: Feminist critical policy analysis matters. J. Higher Edu., 74: 337-349.

Berger, P. and T. Luckman, 1991. The Social Construction of Reality. 1st Edn., Penguin Books, London.

Burr, V., 2003. Social Constructionism. 1st Edn., Psychology Press, ISBN-10: 0415317606, pp: 229.

De Beauvoir, S., 2012. The Second Sex. 1st Edn., Knopf Doubleday Publishing Group, New York, ISBN-10: 030781453X, pp: 832.

Firestone, S., 1974. The Dialectic of Sex: The Case for Feminist Revolution. 1st Edn., Morrow, New York, pp: 274.

FMT, 2013. Teratai state rep Jenice Lee expelled from DAP. Free Malaysia Today.

Fox, W., 1992. Social Statistics Using Microcase. 1st Edn., Nelson-Hall, Chicago, ISBN-10: 0830413154, pp: 331.

Friedl, E., 1975. Women and Men: An Anthropologist's View. 8th Edn., Waveland Press, Prospect Heights, ISBN-10: 088133040X, pp: 148.

Habib, S., 2013. GE13: UMNO sacks 61, including former Wanita No 2 Kamilia Ibrahim (Update).

Hacking, I., 1999. The Social Construction of What? 1st Edn., Harvard University Press, Cambridge, ISBN10: 067481200X, pp: 261.

Hammersly, M., 1992. What's Wrong with Ethnography?: Methodological Explorations? 1st Edn., Psychology Press, ISBN-10: 041505477X, pp: 230.

Harrison, L., 2001. Political Research: An Introduction. 1st Edn., Routledge, London, ISBN 10: 0415226554, pp: 181.

Hawkesworth, M., 1994. Policy studies within a feminist frame. Policy Sci., 27: 97-118. DOI: 10.1007/BF00999883

Kahu, E. and M. Morgan, 2007. A critical discourse analysis of New Zealand government policy: Women as mothers and workers. Women's Studies Int. Forum, 30: 134-146. DOI: 10.1016/j.wsif.2007.01.003 
Kessler, C.S., 2008. A Shared Nation: Constitutionalism, the Social Contract, Mutuality and the Negotiation of Belonging. Sharing the Nation: Faith, Difference, Power and the State 50 Years after Merdeka, Othman, N., M. Puthucheary and C.S. Kessler (Eds.), Strategic Information and Research Development Centre, Petaling Jaya, ISBN-10: 9833782434, pp: 81-88.

Khalid, K.A.T., 2009. Regime for development: Are Asian women still dependent? Int. J. Interdisciplinary Social Sci., 4: 193-208.

Marini, M.M., 1990. Sex and gender: What do we know? Sociological Forum, 5: 95-120. DOI: 10.1007/BF01115139

Mulakala, A., 2013. Where are Malaysia's Women Politicians? In Asia.

Murphy, E., R. Dingwall, D. Greatbatch and P. Parker, 1998. Qualitative research methods in health technology assessment: A review of the literature. Health Technol. Assess., 2: 233-255. PMID: 9919458
Neuman, W.L., 2006. Social Research Methods: Qualitative and Quantitative Approaches. 6th Edn., Pearson, Boston, ISBN-10: 0205457932, pp: 592.

O'Brien, R., A.M. Goetz, J.A. Scholte and M. Williams, 2000. Contesting Global Governance: Multilateral Economic Institutions and Global Social Movements. 1st Edn., Cambridge University Press, Cambridge, ISBN-10: 0521774403, pp: 260.

Sanday, P.R., 1981. Female Power and Male Dominance: On the Origins of Sexual Inequality. 1st Edn., Cambridge University Press, Cambridge, ISBN-10: 0521280753, pp: 295.

SPR, 2013. Keputusan Pilihan Raya.

Star, 2013. Ex-Teratai rep Janice Lee sues DAP over sacking.

Yusof, N.M., 2013. Kamilia Ibrahim beri penjelasan sebab tanding bebas. TELUS and TULUS Sinar Harian. 